\title{
Combined screening for autoantibodies to IA-2 and antibodies to glutamic acid decarboxylase in first degree relatives of patients with IDDM
}

\author{
J. Seissler ${ }^{1}$, N. G. Morgenthaler ${ }^{1}$, P. Achenbach ${ }^{1}$, E. F. Lampeter ${ }^{2}$, D. Glawe ${ }^{1}$, M. Payton ${ }^{3}$, M. Christie ${ }^{3}$, \\ W. A. Scherbaum ${ }^{1}$ and the DENIS Study Group* \\ ${ }^{1}$ Department of Internal Medicine III, University of Leipzig, Leipzig, Germany \\ ${ }^{2}$ Diabetes Research Institute, Düsseldorf, Germany \\ ${ }^{3}$ Department of Medicine, King's College School of Medicine, London, UK
}

Summary To determine the value of antibodies to the intracytoplasmic domain of the tyrosine phosphatase IA-2 (anti-IA-2ic) and glutamic acid decarboxylase (GADA) for identification of subjects at risk for insulin-dependent diabetes mellitus (IDDM) we investigated 1238 first degree relatives of patients with IDDM for the presence of anti-IA-2ic and GADA and compared the results with cytoplasmic islet cell antibodies (ICA). Anti-IA-2ic were observed in 54 $(4.4 \%)$ first degree relatives, in 51 of $86(59.3 \%)$ ICA positive relatives and in 3 of 4 individuals who developed overt IDDM within a follow-up period of 1 to 28 months. GADA were found in 78 of 1238 $(6.3 \%)$ first degree relatives. They were detected in 22 of $35(62.9 \%)$ sera with ICA alone and in 1 of 3 subjects with anti-IA-2 ic in the absence of ICA. Of the 1238 subjects $37(3.0 \%)$ sera were positive for all three antibodies. Both anti-IA-2 ic and GADA were positively correlated with high levels of ICA. AntiIA-2ic and GADA were detected in 39.1 and $47.8 \%$ of subjects with ICA of less than 20 Juvenile Diabetes
Foundation units (JDF-U) but in 66.7 and $76.2 \%$ of individuals with ICA of 20 JDF-U or more, respectively $(p<0.05)$. The levels of ICA and GADA in first degree relatives with at least one additional marker were significantly higher than in subjects with ICA alone $(p<0.005)$ or GADA alone $(p<0.03)$. The combination of anti-IA-2 ic and GADA identified $84.9 \%$ of all ICA positive subjects and $93.7 \%$ of individuals with high level ICA ( $\geq 20$ IDF-U). All 4 individuals who progressed to IDDM had either IA$2 \mathrm{ic}$ or GADA. Our data indicate that primary screening for anti-IA-2 ic and GADA provides a powerful approach with which to identify subjects at risk for IDDM in large-scale population studies which may represent the basis for the design of new intervention strategies. [Diabetologia (1996) 39: 1351-1356]

Keywords Insulin-dependent diabetes mellitus, antibodies to tyrosine phosphatase IA-2, GAD antibodies, islet cell antibodies, prediction.
Insulin-dependent diabetes mellitus (IDDM) is the result of a chronic autoimmune process characterised

Received: 8 March 1996 and in revised form: 29 May 1996

Corresponding author: J. Seissler, MD, Department of Internal Medicine III, University of Leipzig, Ph.-Rosenthal-Str.27, D04103 Leipzig, Germany.

Abbreviations: ICA, Islet cell antibodies, IDDM, insulindependent diabetes mellitus; IAA, insulin autoantibodies; GADA, autoantibodies to glutamic acid decarboxylase; $40 \mathrm{kDa}-\mathrm{ab}$, autoantibodies to $40 \mathrm{kDa}$ antigen; $37 \mathrm{kDa}-\mathrm{ab}$, autoantibodies to $37 \mathrm{kDa}$, antigen; IA-2ic, tyrosine phosphatase IA-2; JDF-U, Juvenile Diabetes Foundation units.

* See acknowledgements by the appearance of several islet cell specific autoantibodies. Various studies have shown that the presence of diabetes-associated autoantibodies in non-diabetic individuals confers increased risk for the future development of IDDM. At present, screening for cytoplasmic islet cell antibodies (ICA) represents the most widely established procedure with which to estimate the risk for IDDM. Depending on the levels of ICA a positive ICA test in first degree relatives of IDDM patients indicates a risk in the range of 34 to $100 \%$ within 10 years [1-4]. The usefulness of ICA for routine screening of susceptible individuals or the general population is, however, limited by the cumbersome nature of the ICA assay and problems 
with the consistency of the test $[5,6]$. Therefore, several studies have analysed the value of other antibody markers for prediction of IDDM.

It has been shown that the prediction of IDDM can be considerably improved by the addition of insulin autoantibodies (IAA), autoantibodies to glutamic acid decarboxylase (GADA) and autoantibodies to $37 \mathrm{kDa}(37 \mathrm{kDa}-\mathrm{ab})$ and $40 \mathrm{kDa}(40 \mathrm{kDa}-\mathrm{ab})$ antigens in ICA positive individuals [7-12]. Primary screening for either IAA or GADA alone, however, has proved to be less specific than ICA testing [7, 13-15]. In contrast, $37 \mathrm{kDa}-\mathrm{ab}$ and $40 \mathrm{kDa}-\mathrm{ab}$ have been reported to be strongly associated with rapid progression to IDDM, but like other markers these antibodies are unable to identify all individuals who later develop IDDM $[4,11]$. Due to the labour intensive test procedure using radiolabelled islet cells, it has been difficult to screen large numbers for $37 \mathrm{kDa}-\mathrm{ab} / 40 \mathrm{kDa}-$ ab so far [16]. Recently, Christie and co-workers [16, 17] identified the $40 \mathrm{kDa}$ antigen as the intracytoplasmic domain of the tyrosine phosphatase IA-2 (IA2 ic) $[17,18]$. With the cloning of the human IA-2 cDNA, population-based screening for autoantibodies to IA-2 is now possible. In this study we describe a radiobinding assay which allows quantitative measurement of autoantibodies to IA-2 ic (anti-IA$2 \mathrm{ic}$ ) on a large scale. We also show population-based data on the prevalence of IA-2 antibodies and demonstrate that combined screening for anti-IA-2ic and GADA identify almost all subjects with high levels of ICA in first degree relatives of patients with IDDM. These data suggest that screening for antibodies to IA-2 in combination with GADA may represent a powerful strategy for routine screening to identify subjects at increased risk for IDDM.

\section{Subjects and methods}

Patients. Sera were obtained from the first sample of 1238 nondiabetic first degree relatives of IDDM patients (663 females, 575 males; age 0.1 and 57 years, mean age $12.7 \pm 11.6$ years), who were recruited by the screening programme of the Deutsche Nikotinamid Interventions-Studie (DENIS). Sera of probands participating in the DENIS Study were collected before the start of study treatment. Sera from 100 healthy individuals (mean age 16.5 years, range 7-28 years) without a family history of IDDM were used as controls. Informed consent was obtained from the subjects or their parents. The study was approved by the ethical committees of the centres participating in the study.

Detection of autoantibodies to human recombinant GAD 65 and $I A-2$. Autoantibodies to the intracytoplasmic domain of IA-2 (anti-IA-2 ic) and GADA were determined using radiolabelled human recombinant antigens in a 96-well assay format. Recombinant autoantigens were produced by coupled in vitro transcription and translation (Promega, Madison, Wis., USA) of human IA-2 ic cDNA, coding for IA-2 ic (amino acids 603980) [17] and human GAD 65 cDNA (a kind gift of Å. Lernmark, Seattle, USA) [19], respectively.
Plasmid cDNA $(1 \mu \mathrm{g})$ coding either for GAD 65 or IA-2 ic was incubated with the reticulocyte lysate system and ${ }^{35} \mathrm{~S}$ methionine $(10 \mathrm{mCi} / \mathrm{ml},>1000 \mathrm{Ci} / \mathrm{mmol}$; Amersham Ltd., Amersham, Bucks., UK) according to the manufacturer's instructions. Incorporation of radioactivity in recombinant proteins was monitored by precipitation with trichloroacetic acid. We incubated $10,000 \mathrm{cpm}$ of in vitro synthesized IA$2 \mathrm{ic}$, or $20,000 \mathrm{cpm}$ of GAD 65 with $5 \mu \mathrm{l}$ serum diluted in $50 \mu$ l buffer A (mmol/l 20 Tris, $150 \mathrm{NaCl}, \mathrm{pH} 7.4$ with $0.1 \%$ bovine serum albumin, 5 methionine, 5 benzamidine, 2 PMSF, 2 EDTA, $0.1 \%$ trasylol, $0.5 \%$ Triton X 100) in 96well microtitre plates (Greiner, Nürtingen, Germany). After overnight incubation on a rotating platform $20 \mu$ l Protein A Sepharose $(50 \% \mathrm{v} / \mathrm{v})$ was added for $2 \mathrm{~h}$ followed by the transfer of the probes into prewashed 96-well filtration plates (Multiscreen BV $1.2 \mu \mathrm{m}$; Millipore, Bedford, Mass., USA). Plates were extensively washed in buffer A $(15 \times 150 \mu \mathrm{l})$ and precipitates were punched out into $5 \mathrm{ml}$ scintillation vials (Multiple 8-punch system; Millipore) to count bound proteins in a liquid scintillation counter. Alternatively, immunoprecipitates were subjected to SDS-PAGE and analysed by autoradiography. In each experiment the same positive and negative standard sera were included in duplicates. Antibody levels were expressed as arbitrary units (AU) calculated as follows: $\mathrm{U}=(\mathrm{cpm}[$ test serum] $-\mathrm{cpm}[$ negative standard serum] $)$ / (cpm[positive standard serum] - cpm(negative standard serum]) $\times 100$. Intra-assay and inter-assay coefficients of variation of the IA-2ic antibody assay were $7.7 \% \quad(n=9)$ and $10.9 \%(n=9)$, respectively. To achieve high specificity of antibody detection the cut off for antibody positivity was set at mean + 4 SD of antibody levels in 100 normal control sera (7 GAD-U and 3 IA-2-U). In the Second GAD Antibody Proficiency Program our GADA assay achieved 100\% sensitivity and $100 \%$ specificity.

Detection of cytoplasmic ICA. Islet cell antibodies were detected by the indirect immunofluorescence test on unfixed cryostat sections of human pancreas from an organ donor with blood group 0 as described [20]. Determinations were carried out on the same tissue and the results were expressed in Juvenile Diabetes Foundation JDF units according to the workshop protocol for the standardisation of ICA. The detection limit of the assay in our laboratory was 3 JDF-U. In the 10 th International Diabetes Workshop ICA Proficiency Program our laboratory achieved values of $90 \%$ for sensitivity and $100 \%$ for specificity (Laboratory identification No 298).

\section{Statistical analysis}

The significance of differences between observations was tested using the Wilcoxon test, the chi-square test with Yates' correction, Fisher's exact test, or Mann-Whitney test where appropriate. The significance of correlations between antibodies was tested by Spearman rank correlation analysis.

\section{Results}

Prevalence of autoantibodies. Among 1238 non-diabetic first degree relatives of patients with IDDM 54 $(4.4 \%)$ were positive for anti-IA-2ic (mean age $10.5 \pm 9.9$ years, 26 females, 28 males $), 78(6.3 \%)$ had GADA (mean age $11.0 \pm 8.9$ years, 35 females, 
Table 1. Antibodies to IA-2 ic (anti-IA-2 ic), antibodies to glutamic acid decarboxylase (GADA) and cytoplasmic islet cell antibodies (ICA) in first degree relatives of patients with IDDM stratified by age

\begin{tabular}{lrlrr}
\hline $\begin{array}{l}\text { Subjects } \\
\text { Age (years) }\end{array}$ & Number & \multicolumn{3}{l}{ Prevalence of autoantibodies } \\
\cline { 3 - 5 } & & Anti-IA-2ic & GADA & \multicolumn{1}{c}{ ICA } \\
\hline $0-6$ & 443 & $19(4.3)$ & $28(6.3)$ & $25(5.6)$ \\
$7-12$ & 494 & $27(5.5)$ & $32(6.5)$ & $44(8.9)$ \\
$13-18$ & 99 & $4(4.0)$ & $11(11.1)$ & $9(9.1)$ \\
$19-30$ & 43 & $2(4.7)$ & $2(4.7)$ & $2(4.7)$ \\
$>31$ & 159 & $2(1.3)$ & $5(3.1)$ & $6(3.8)$ \\
Total & 1238 & $54(4.4)$ & $78(6.3)$ & $86(6.9)$ \\
\hline
\end{tabular}

Data are $n(\%)$

43 males) and $86(6.9 \%)$ were ICA positive (mean age $11.4 \pm 8.8$ years, 39 females, 47 males). Only 1 of $100(1.0 \%)$ normal control subjects had GADA (range 0-9.0 GAD-U), and none of 100 individuals were positive for anti-IA-2 ic (range 0-2.8 IA-2 ic-U) or ICA $(p<0.05)$ (Table 1$)$. Of these subjects 33 $(2.7 \%)$ were positive for only one test, while 37 $(3.0 \%)$ subjects had two markers and $37(3.0 \%)$ subjects were found positive for all three markers, i.e. ICA, anti-IA-2 ic and GADA. There was no significant association of any antibody with age or gender.

Association between IA-2 ic antibodies, GADA and $I C A$. The distribution of the three antibody specificities within the study population is illustrated in Figure 1. Both anti-IA-2 ic as well as GADA were positively associated with the presence of ICA. IA-2 ic antibodies were detected in $51(59.3 \%)$ and GADA in $59(68.6 \%)$ of 86 ICA positive subjects, respectively $(p<0.0001)$ (Fig. 1). Significantly higher frequencies of anti-IA-2 ic and GADA were found in subjects with ICA levels of $20 \mathrm{JDF}-\mathrm{U}$ or more (42/ $63[66.7 \%]$ and $48 / 63[76.2 \%], p<0.05)$ or with ICA levels of $40 \mathrm{JDF}-\mathrm{U}$ or more (35/50 [70.0\%] and $40 / 50[80.0 \%], p<0.02)$ compared to individuals with ICA less than $20 \mathrm{JDF}-\mathrm{U}(9 / 23$ [39.1\%] positive for anti-IA-2ic and 11/23 [47.8\%] GADA positive). Combined screening for the presence of either antiIA- 2 ic or GADA identified $84.9 \%$ of all ICA positive relatives. Most strikingly, anti-IA-2 ic or GADA were present in $93.7 \%(59 / 63)$ and $96.0 \%(48 / 50)$ subjects with ICA levels $20 \mathrm{JDF}-\mathrm{U}$ or more and $40 \mathrm{JDF}-\mathrm{U}$ or more, respectively (Fig. 2). As illustrated in Figure 2 only 3 of $1152(0.26 \%)$ ICA negative relatives had anti-IA-2ic. In one of these three cases high levels of GADA (80.2 GAD-U) were also detected. Out of 35 ICA positive anti-IA-2ic negative sera $22(62.9 \%)$ were found to be positive for additional GADA. GADA in the absence of ICA and anti-IA-2ic were observed in 18 of 78 $(23.1 \%, 1.5 \%$ of the total population) GADA positive subjects, which is similar to the prevalence of GADA observed in normal control subjects $(1.0 \%)$.

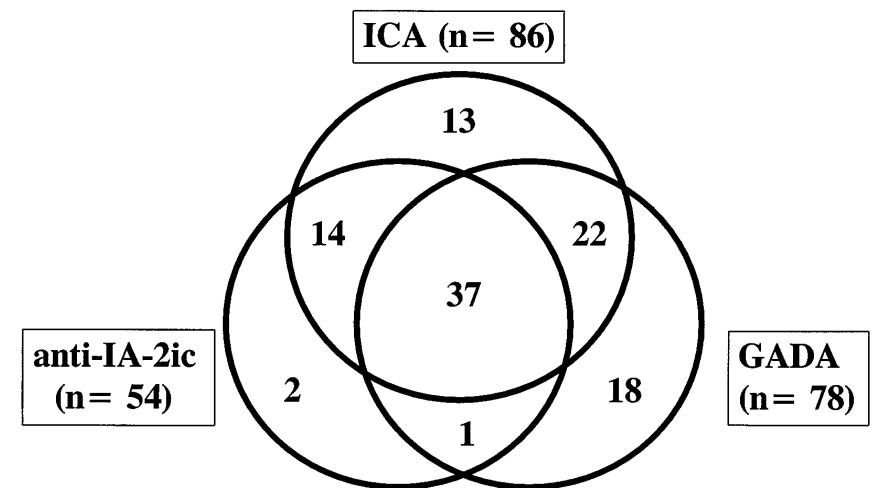

Fig. 1. Combinations of autoantibodies in 107 antibody positive first degree relatives of patients with IDDM. Antibodies to IA-2 ic (anti-IA-2 ic), antibodies to glutamic acid decarboxylase (GADA) and cytoplasmic islet cell antibodies (ICA)

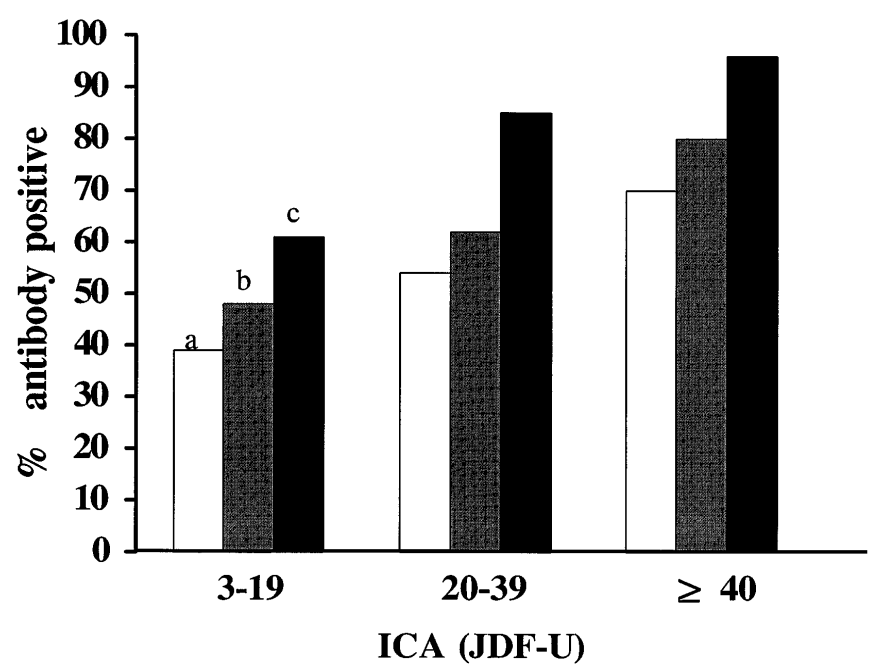

Fig. 2. Association of antibodies to IA-2 ic (anti-IA-2ic) and antibodies to glutamic acid decarboxylase (GADA) grouped according to levels of islet cell antibodies (ICA). Anti-IA-2 ic positive $(\square)$; GADA positive $(\square)$; anti-IA-2ic positive and/ or GADA positive (1). a $p<0.02$; b $p<0.01$; c $p<0.0005$ vs subjects with ICA $\geq 40 \mathrm{JDF}-\mathrm{U}$

In the 13 relatives who had ICA alone $(1.1 \%$ of the total population), ICA levels (15.8 $\pm 11.5 \mathrm{JDF}-\mathrm{U})$ were significantly lower than in sera with one $(30.2 \pm 16.1$ JDF-U, $p<0.005)$ or two additional markers $(33.9 \pm 14.6$ JDF-U, $p<0.0005)$. A similar result was observed when GADA levels were compared between single GADA positive sera $(31.3 \pm 16.8$ GAD-U) and sera with two or three autoantibodies $(56.3 \pm 28.2$ GAD-U) $(p<0.03)$. Analysis of autoantibody levels in individual sera revealed a significant correlation between ICA and anti-IA2 ic $(r=0.59,95 \%$ confidence interval: $0.44-0.70$, $p<0.001)$ as well as ICA and GADA $(r=0.21$, $95 \%$ confidence interval: $0.01-0.39, p<0.05)$. There was no correlation between the levels of anti-IA-2 ic and GADA (Fig. 3). 

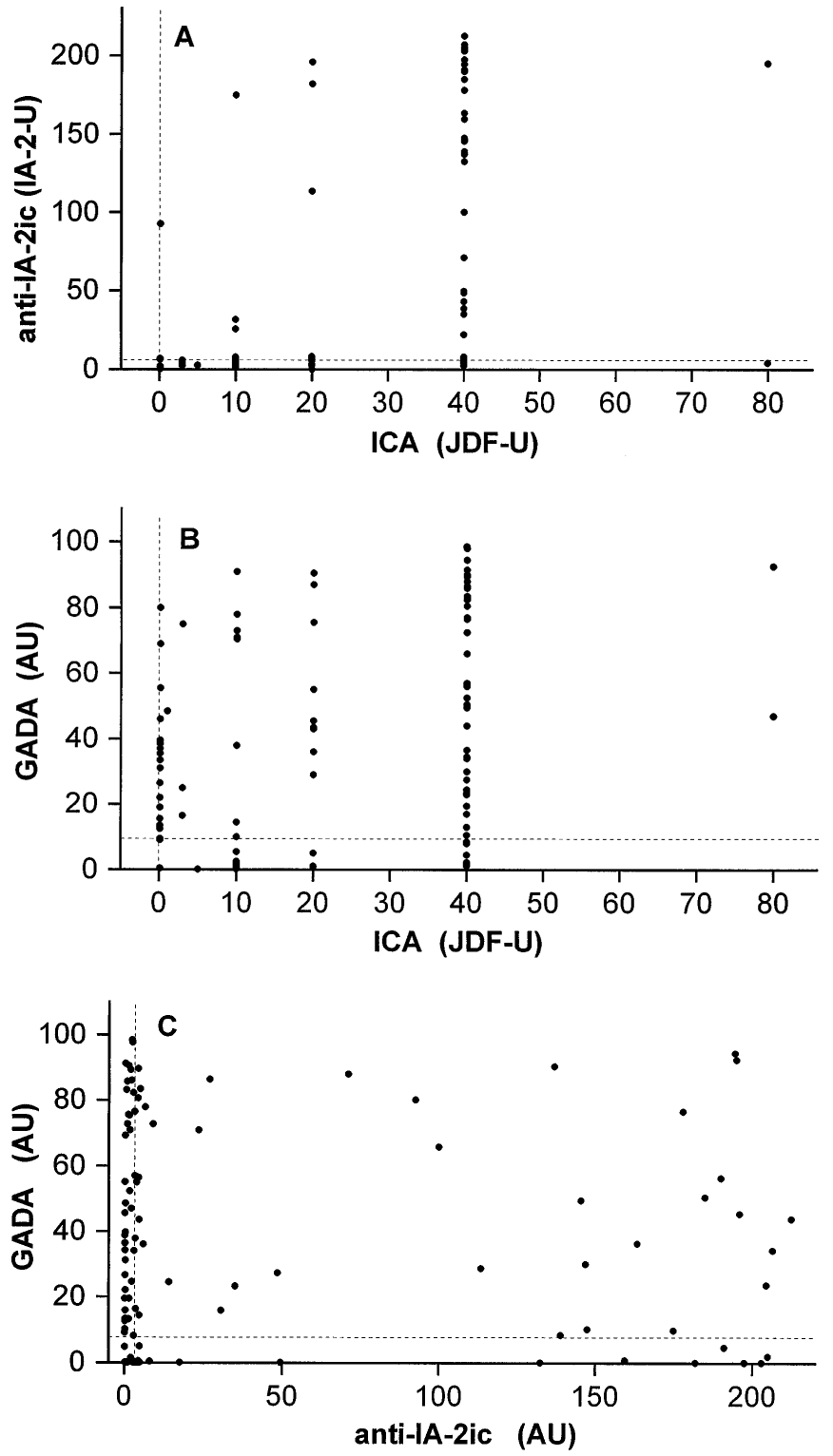

Fig.3. A-C Relationship between autoantibody levels in first degree relatives of patients with IDDM. Levels of islet cell antibodies (ICA) were compared with levels of antibodies to IA2 ic (anti-IA-2 ic) (A) and levels of antibodies to glutamic acid decarboxylase (GADA) (B). The levels of anti-IA-2 ic were correlated with levels of GADA (C). Anti-IA-2 ic and GADA levels are expressed in arbitrary units (AU) and ICA are given in JDF-U

Follow-up investigation. During a mean follow-up of 23 months (range 1-31 months) 4 out of 107 autoantibody positive subjects ( 3 females, 1 male; mean age $9.3 \pm 3.2$, range $5.8-13.5$ years) but none of the antibody negative individuals developed overt IDDM. At initial screening $(1,14,16$ and 28 months before the development of IDDM) all prediabetic subjects were positive for ICA (40 JDF-U). In one child high levels of anti-IA-2ic (163 IA-2-U) and GADA (36 GAD-U) were present; two children had high levels of anti-IA-2 ic (173 and 160 IA-2-U) but were negative for GADA (1.9 and 0.8 GAD-U) and one child was GADA positive (13 GAD-U) and anti-IA-2 ic negative (1.4 IA-2U). All 4 prediabetic subjects were positive for either anti-IA-2 ic or GADA.

\section{Discussion}

In this study we assessed the value of antibodies to human recombinant IA-2 and GAD to identify subjects at increased risk for IDDM in a large population of first degree relatives of patients with IDDM. Since the short follow-up period does not allow accurate analysis of the predictive value of the antibodies, we compared anti-IA-2 ic and GADA with ICA which is the best validated serological marker found so far to estimate the risk for IDDM [1-4]. We report here that combined screening for anti-IA-2ic and GADA detected more than $93 \%$ of subjects who possess a high risk for IDDM on the basis of high ICA titres, and all 4 individuals who subsequently developed overt IDDM during the follow-up period were positive for either anti-IA-2ic or GADA. The use of 96well radiobinding techniques to measure these antibodies allows rapid and quantitative screening for autoantibodies on a large scale, overcoming some of the limitations of the ICA test $[5,6]$.

Anti-IA-2 ic were found to be present in $4.4 \%$ of the large cohort of 1238 first degree relatives which is a prevalence comparable with the frequencies of ICA or IAA reported from several family studies and is similar to the estimated cumulative incidence of IDDM in first degree relatives $[1-3,7]$. We observed a strong association of anti-IA-2 ic with the presence of ICA confirming previous reports on antibodies to the $37 \mathrm{kDa} / 40 \mathrm{kDa}$ antigens $[4,10,12$, 21]. Thus, ICA were present in all but three sera with anti-IA-2ic. Conversely, anti-IA-2 ic were found in $59.3 \%$ of subjects with detectable ICA $(\geq 3 \mathrm{JDF}-\mathrm{U})$. The prevalence of anti-IA-2ic in ICA positive subjects was higher than in previous studies where antibodies to the $37 \mathrm{kDa} / 40 \mathrm{kDa}$ antigens were detected in only $17 \%$ of ICA positive first degree relatives $[4,21]$. These studies are not strictly comparable because of differences in protocols for measurement of autoantibodies. The use of recombinant antigen in radioligand binding assays may increase the sensitivity of detection, as described for GADA [22-24]. Anti-IA-2 ic were detected in 3 of the 4 subjects who progressed to IDDM during a mean follow up period of 23 months. The high prevalence of anti-IA-2 ic in prediabetic and ICA positive relatives is consistent with previous reports which have described antibodies to the $40 \mathrm{kDa}$ antigen in a high proportion of prediabetic relatives and ICA positive patients with recent-onset IDDM [4, 10, 11]. The segregation of anti-IA-2 ic positive relatives in a subgroup of ICA positive subjects with high risk for IDDM indicates 
that these antibodies are valuable tools in the prediction of IDDM.

Although a large proportion of ICA positive subjects are identified by anti-IA-2ic, primary screening for anti-IA-2 ic alone does not detect all the individuals at risk for IDDM. To improve sensitivity we combined anti-IA-2ic with GADA which can be easily detected using recombinant antigen in the same assay format [25]. As for anti-IA-2ic, GADA were positively associated with the presence of ICA, and in particular with high levels of ICA. These findings are in agreement with previous observations on a preferential occurrence of GADA in ICA positive prediabetic subjects and patients with IDDM [22, 25-27]. Positivity for GADA alone, in the absence of other antibody markers, which is known to be correlated with a low risk for IDDM $[13,14]$, was observed in only $1.5 \%$ of the total population. Although screening for GADA may identify individuals who are unlikely to develop IDDM, these are rare. It is important to note, however, that GADA identified $62.9 \%$ of ICA positive subjects who were negative for antiIA-2 ic. Risk estimation in several family studies revealed that the additional presence of GADA in sera of ICA positive first degree relatives indicates an increased risk for IDDM. Inclusion of GADA may thus complement anti-IA-2ic in screening programmes and may increase sensitivity for prediction of IDDM $[4,12]$. Despite a high correlation between GADA or anti-IA-2 with ICA 13 (1.05\% of the study population) individuals were found exclusively ICA positive. Of those 13 subjects $9(69.2 \%)$ had ICA levels of less than 10 JDF-U indicating that only a small number of subjects who may progress to overt IDDM might be missed by the combined screening of anti-IA-2 ic and GADA.

In conclusion, the use of human recombinant autoantigens IA-2 and GAD made it possible to develop radiobinding assays which allow rapid and sensitive detection of two major targets of humoral autoimmunity in IDDM. Our findings indicate that the combination of anti-IA-2ic and GADA can accurately identify subjects at risk for IDDM identified on the basis of ICA positivity. The present approach offers an alternative strategy which might possess the power to replace ICA for primary screening in large-scale population studies. At present the use of both antiIA- 2 ic and GADA is limited by the still unknown predictive values of both markers which need to be validated in prospective family studies and the general population. Accurate risk estimation, however, can be achieved by a two-step procedure whereby initial combined screening for GADA and anti-IA-2 ic is followed by scoring of ICA in those subjects positive for one marker. This strategy may considerably facilitate population-based screening programmes to identify subjects for intervention trials to prevent the development of IDDM.
Acknowledgements. We thank Drs. Å. Lernmark, A.E. Karlsen and C.E. Grubin for the gift of human GAD 65 cDNA. We thank all the parents and children who agreed to participate in the study and we gratefully acknowledge the members of the DENIS Study Advisory Board (Prof. E. Heinze, Prof. K. Federlin, Prof. H.Kolb, Prof. W. A. Scherbaum) and the physicians from all the hospitals and clinics taking part in the DENIS Study:

D. Agena (Hildesheim), P. Amendt (Berlin), W. Andler (Datteln), J. Aring (Remscheid), J. Bachmann (Bremen), K. Badenhoop (Frankfurt), C. Baisch (Friedrichshafen), F. Baumeister (München), A.Beck (Mainz), C.Becker (Pirna), W.Beischer (Stuttgart), J.Bender (Wiesbaden), B. Bennfeldt (Hamburg), C. Bernuth (Bielefeld), J.Bertrams (Essen), P. Beyer (Oberhausen), C.Bitter-Klink (Lörrach), H.Böhles (Frankfurt), K.Böhmer (Nürnberg), M.Borkenstein (Graz), M.Borte (Leipzig), C.Brack (Celle), R. G. Bretzel (Gießen), R. Burghard (Memmingen), M.Busse (München), H. Caspar (Mönchengladbach), M. Cierpka (Göttingen), H.Cremer (Heilbronn), K. Cremer (Siegen), T. Danne (Berlin), M.Diensberg (Wetter), M.Dünkel (Speyer), R. Dürr (Waiblingen), K. Eickhoff (Ludwigshafen), J.Etspüler (Lübeck), A.Fickert (Plauen), D. Folkens (Offenburg), F. Franke (Gronau), G. Friedrich (Ahlen/Westf.), H. Geiger (Schwäbisch Hall), H. Giesen (Schweinfurt), R. Glaser (Sigmaringen), F. GlauberPrang (Hannover), G. Griefhahn (Greifswald), F. A. Gries (Düsseldorf), H.Gröbe (Nürnberg), I.Grübner (Jena), U. Grumpelt (Magdeburg), H. Haberland (Berlin), L. Hansen (Ravensburg), H.Haug (Ludwigsburg), H.Hausmann (Plauen), W.Hecker (Stuttgart), P.H. Heidemann (Augsburg), H.Heineken (Düsseldorf), E.Hellwig (Freiburg), D.Henker (Dresden), A.Hennig (Cottbus), R. Henrichs (Quakenbrück), I. A. Henrichs (Neuburg a.d. Donau), J.Herwig (Frankfurt), V.Hesse (Berlin), I.Hild (Mannheim), B.Höhmann (Aalen), R.Holl (Ulm), J.Hottenbacher (Kassel), K.Hübschmann (Potsdam), P.Hürter (Hannover), W.Jacopian (Potsdam), C. Jäger (Gießen), F. Janssen (Bielefeld), H. U. Jastram (Kaiserslautern), M.Kandler (Erlangen), H. Kauf (Jena), S. Kehr (Kempten), H. Kendler (Wismar), W. Kiess (Gießen), L. Kininger (Mainz), A.Kirch (Krefeld), H. Klein (Bad Nauheim), R. Klick (Mechernich), A. Klinghammer (Chemnitz), M. Koch (Münster), H.Koch (Vechta), G.Köhler (Wendelstein), P. Koepp (Wismar), B. Kohout (Koblenz), N. Kollmann (Waiblingen), A. Kornmann-Hecker (München), P.Kotanko (Graz), U.M. Kraft (Fulda), D. Krüger (Minden), E.F. Lampeter (Düsseldorf), E.Lang (Coesfeld), A.Lauterborn (Berlin), B.Legrand (Neuwied), J.Leititis (Freiburg), A.Lemmer (Erfurt), K.Lepler (Hamburg), C.Luddeke (München), K.H.D. Ludwig (Trier), E.Ludwig (Freudenstadt), J.Luthardt (Worms), F.Lycko (Bochold), W. Marg (Bremen), D. Matern (Freiburg), H. Mattern (Göppingen), G. Mau (Braunschweig), L.Maué (Bonn), G. Meinecke (Kiel), B.Meyburg (Heidelberg), D. Michaelis (Karlsburg), B. Middeke (Bad Kissingen), M. Mix (Rostock), K. Mühlendahl (Osnabrück), W. Müller (Mannheim), G. Neßler (Karlsruhe), A.Neter (Hannover), A.Neu (Tübingen), U.Nietzschmann (Leipzig), V.Nowoczyn (Münster), M. Oberle (Göppingen), J. Oldenburg (Flensburg), D. Oppermann (Cottbus), C. Osswald (Singen), A. Otten (Hamm), I.Passauer (Dresden), R. Petzoldt (Bad Oeynhausen), U.Preiß (Halle-Kröllwitz), W. Rabl (München), B. Ranke (Tübingen), W.Rauh (Trier), K.M.Reinauer (Tübingen), T. Reiners (Viersen), L. Reinken (Hamm), R. Reiß (Hagen), C.Renner (Erlangen), J.Rickers (Osnabrück), M. Rohe (Quakenbrück), U.Roschlau (Düsseldorf), R. Roth (Göttingen), R. Roth (Graz), G.Schädel (Schwäbisch Gmünd), J. Schaub (Kiel), B.Schenk (Schwerin), R.Schille (Leipzig), 
H.Schmidt (Heidelberg), F.Schmidt (Böblingen), W.Schmidt (Hannover), R.Schnarz (Pforzheim), E.Schober (Wien), S.Schukowski (Bergen), T.Schulte-Wissermann (Krefeld), J.Schulze (Dresden), A.Schumacher (Göppingen), C. Schütz (Regensburg), D.Schweigert (Detmold), P.Schweikhardt (Heidenheim), J.Schwingshandl (Graz), P.Sehlen (Oldenburg), G.H. Sinnecker (Lübeck), R. Stachow (Hamburg), M. Stahl (Lörrach), N. Stanke (Hamburg), H. Steinhauer (Krefeld), P.Steins (Ravensburg), K.Stolzenbach (Hamburg), D. Stolzenberg (Dessau), K. Strube (Suhl), H. Taut (Dresden), G. Thiele (Freiburg), A. Thon (Hannover), H. U. Tietze (Nürnberg), W.Tillmann (Minden), U.Töllner (Fulda), P.Tosberg (Ravensburg), K. Uhlig (Lippstadt), J. Unsinn (Innsbruck), K.H. Usadel (Frankfurt), V.Brenndorf (Heidenheim), V.Schnakenburg (St. Augustin), H.J. Verlohren (Leipzig), C. Vogel (Chemnitz), V.Lilien-Waldau (Düsseldorf), G. Wässer (Ludwigslust), V.Wagner (Lübeck), R. Wahlen (Homburg), U. Walther (Fürth), B. Weber (Berlin), E. Weiblen (Winnenden), U. Weiß (Aue), D. Weitzel (Wiesbaden), D. Wiemann (Magdeburg), W. Winkler (Bad Kreuznach), K. Wogall (Gießen), J. Wolf (Paderborn), L.Wündisch (Bayreuth), S. Zabransky (Homburg), R. Zeller (Aschaffenburg), R. Ziegler (Münster), K. Zimmermann (Celle), L. Zinn (Speyer).

The study was supported by the Deutsche Forschungsgemeinschaft Se 725/1-1, the Deutsche Diabetes Gesellschaft (WAS, EFL and JS), and the Juvenile Diabetes Foundation International grant \#192932 to WAS).

\section{References}

1. Tarn AC, Thomas JM, Dean BM et al. (1988) Predicting insulin-dependent diabetes. Lancet i: $845-850$

2. Bonifacio E, Bingley PJ, Shattock M et al. (1990) Quantification of islet-cell antibodies and prediction of insulin-dependent diabetes. Lancet 335: 147-149

3. Riley WJ, MacLaren NK, Kirscher N et al. (1990) A prospective study of the development of diabetes in relatives of patients with insulin-dependent diabetes. N Engl J Med 323: 1167-1172

4. Bingley PJ, Christie MR, Bonifacio E et al. (1994) Combined analysis of autoantibodies improves prediction of IDDM in islet cell antibody-positive relatives. Diabetes 43: $1304-1310$

5. Bonifacio E, Boitard C, Gleichmann H, Shattock MA, Molenaar LJ, Bottazzo GF (1990) Assessment of precision, concordance, specificity and sensitivity of islet cell antibody measurement in 41 assays. Diabetologia 33: 731-736

6. Greenbaum CJ, Palmer JP, Nagataki S et al. (1992) Improved specificity of ICA assays in the Fourth International Immunology of Diabetes serum exchange Workshop. Diabetes 41: 1570-1574

7. Roll U, Christie MR, Standl E, Ziegler A (1994) Associations of anti-GAD antibodies with islet cell antibodies and insulin autoantibodies in first-degree relatives of type 1 diabetic patients. Diabetes 43: 154-160

8. Seissler J, Hering B, Richter W et al. (1992) Antibodies to the $M_{r} 64,000(64 \mathrm{~K})$ protein in islet cell antibody positive non-diabetic individuals indicate high risk for impaired beta-cell function. Diabetologia 35: 550-554

9. Chaillous L, Delamaire M, Elmansour A et al. (1994) Combined analysis of islet cell antibodies which cross-react with mouse pancreas, antibodies to the $M_{r} 64,000$ islet cell protein, and antibodies to glutamate decarboxylase in subjects at risk for IDDM. Diabetologia 37: 491-499
10. Christie MR, Tun RYM, Lo SSS et al. (1992) Antibodies to GAD and tryptic fragments of islet $64 \mathrm{~K}$ antigen as distinct markers for development of IDDM. Diabetes 41: 782-786

11. Christie M, Genovese S, Cassidy D et al. (1994) Antibodies to islet $37 \mathrm{~K}$ antigen, but not to glutamate decarboxylase, discriminate rapid progression to IDDM in endocrine autoimmunity. Diabetes 43: 1254-1259

12. Bonifacio E, Genovese S, Braghi S et al. (1995) Islet autoantibody markers in IDDM: risk assessment strategies yielding high sensitivity. Diabetologia 38: 816-822

13. Aanstoot HJ, Sigurdsson E, Jaffe M et al. (1994) Value of antibodies to $\mathrm{GAD}_{65}$ combined with islet cell cytoplasmic antibodies for predicting IDDM in a childhood population. Diabetologia 37: 917-924

14. Yu L, Gianani R, Eisenbarth GS (1994) Quantitation of glutamic acid decarboxylase autoantibody levels in prospectively evaluated relatives of patients with type 1 diabetes. Diabetes 43: 1229-1233

15. Schott M, Schatz D, Atkinson M et al. (1994) GAD 65 autoantibodies increase the predictability but not the sensitivity of islet cell and insulin autoantibodies for developing insulin dependent diabetes mellitus. J Autoimmun 7: 865-872

16. Christie M, Hollands JA, Brown TJ, Michelsen BK, Delovitch TL (1993) Detection of pancreatic islet 64,000 Mr autoantigens in insulin-dependent diabetes distinct from glutamate decarboxylase. J Clin Invest 92: 240-248

17. Payton MA, Hawkes CJ, Christie MR (1995) Relationship of the 37,000- and 40,000 Mr tryptic fragments of islet antigens in insulin-dependent diabetes to the protein tyrosine phosphatase-like molecule IA-2 (ICA512). J Clin Invest 96: 1506-1511

18. Lan MS, Goto Y, Notkins AL (1994) Molecular cloning and identification of a receptor-type protein tyrosine phosphatase, IA-2, from human insulinoma. DNA Cell Biol 5: 505-514

19. Grubin CE, Daniels T, Toivola B et al. (1994) A novel radioligand binding assay to determine diagnostic accuracy of isoform-specific glutamic acid decarboxylase antibodies in childhood IDDM. Diabetologia 37: 344-350

20. Scherbaum WA, Mirakian R, Pujol-Borrell R, Dean BM, Bottazzo GF (1986) Immunochemistry in the study and diagnosis of organ-specific autoimmune disease. In: Polak JM, Van Noorden S (eds) Immunochemistry. Modern methods and applications. Wright, Bistrol; pp 456-476

21. Ongagna CJ, Marchal-Levy C (1995) Anti-37kDa antibodies are associated with the development of IDDM in individuals with islet cell antibodies. Diabetologia 38: 370-375

22. Seissler J, Amann J, Mauch L et al. (1993) Prevalence of autoantibodies to the $65-$ and $67-\mathrm{kD}$ isoforms of glutamate decarboxylase in insulin-dependent diabetes mellitus. J Clin Invest 92: 1394-1399

23. Schmidli RS, Colman PG, Bonifacio E, and participating laboratories (1995) Disease sensitivity and specificity of 52 assays for glutamic acid decarboxylase antibodies. The second international GADAb workshop. Diabetes 44: 636-640

24. Gianini R, Rabin DU, Verge CF et al. (1995) ICA 512 autoantibody radioassay. Diabetes 44: 1340-1344

25. Verge CF, Howard NJ, Rowley MJ et al. (1994) Anti-glutamate decarboxylase and other antibodies at the onset of childhood IDDM: a population-based study. Diabetologia 37: 1113-1120

26. Hagopian WA, Sanjeevi CB, Kockum I et al. (1995) Glutamate decarboxylase-, insulin-, and islet cell-antibodies and HLA typing to detect diabetes in a general populationbased study of Swedish children. J Clin Invest 95: 1505-1511

27. Petersen JS, Hejnaes KR, Moody A et al. (1994) Detection of $\mathrm{GAD}_{65}$ antibodies in diabetes and other autoimmune diseases using a simple radioligand assay. Diabetes 43: 459-467 